Korenyeva Oksana, Ph. D, Associate Professor, Departament of Banking, Sysoyeva Larysa, Ph. D, Associate Professor, Departament of Banking, Belova Inna, Ph. D, Associate Professor,

Departament of Banking Ukrainian Academy of Banking of the National Bank of Ukraine

\title{
The influence of globalization and integration process on the activities of the banking system of Ukraine
}

Summary. In this paper the influence of globalization and integration processes on the structure of the banking sector of Ukraine is investigated. Positive and negative effects of the Ukrainian banking system openness are identified. The common trends and consequences of increasing the share of foreign investments in Ukraine's banking system are analyzed. Suggestions for preventing the negative impact of foreign bank capital are elaborated.

Keywords : globalization, foreign capital, the banking sector, integration

Introduction. Under conditions of globalization and European integration processes Ukraine can not develop in isolation from the global economic system. Strengthening influence of financial globalization on national economies is a characteristic feature of modern international economic relations. Intensification of integration process in the financial markets, competition for access to capital, technology mediation development, financial instruments standardization and free movement of capital are the reflection of these processes. Financial globalization and integration that causes aggravation of the international banking competition deals with the origin of some positive factors of influence. At the same time, global financial crisis provoke crisis on domestic banking markets. In this context the 
investigation of globalization processes impact on the banking system of Ukraine, which stipulates the need to study the impact of foreign capital on the Ukrainian banks is certainly important.

In recent years, considerable attention is given to investigation of theoretical and practical principles of integration processes in the domestic banking market. Various aspects of these problems were studied by foreign scientists Van den Berghe [1], K. Verweire [1], V.M. Carchon [1] I. Tytell [2] and others. A lot of studies in this area have recently appeared in national science. We can distinguish works of A. Baranovsky [3], V. Geytsa [4], V. Kovalenko [5], A. Epifanova [6] and others.

Problem. Despite the increasing relevance of the impact of globalization and integration processes in the development of the domestic banking sector, in the theory and practice prevail selective approach to covering a range of issues and dynamics of the banking market development and economic change in environmental conditions require further research in this direction.

Foreign capital entry to the domestic financial markets is a typical manifestation of globalization process in financial relations that deals with the emergence of its possible influence on the development of national financial systems.

The share of foreign capital in Ukraine and number of mergers and acquisitions are annually increasing, that illustrates the data in Table 1 :

Table 1 - Acquisition and merges market in the financial sector of Ukraine [7]

\begin{tabular}{|c|c|c|c|}
\hline Year & $\begin{array}{l}\text { Total value of transactions, } \\
\text { bln } \$\end{array}$ & $\begin{array}{l}\text { Number of } \\
\text { transactions }\end{array}$ & $\begin{array}{l}\text { Average value of } \\
\text { transactions, bln } \$\end{array}$ \\
\hline 2006 & 3,72 & 109 & 0,034 \\
\hline 2007 & 22,19 & 86 & 0,260 \\
\hline 2008 & 3,32 & 40 & 0,080 \\
\hline 2009 & 5,44 & 35 & 0,160 \\
\hline 2010 & 5,97 & 36 & 0,180 \\
\hline
\end{tabular}

The rapid development of the banking sector and economic growth in Ukraine turned the domestic banking market into the one of the most attractive for capital in Eastern Europe. Moreover, coverage of Ukraine by foreign capital is determined by the peculiarities of its development. The process of financial globalization and 
integration acquired particular manifestation by foreign capital entering through the purchase of Ukrainian banks, their acquisition or creation of new banks with foreign capital.

Bank-centric nature of financial market caused increased interest in global financial services, primarily, to the banking market of Ukraine. Since 2006 there was a significant increase of foreign capital in the banking system of Ukraine. Legislation makes it possible to create banks in Ukraine with $100 \%$ foreign capital, but with a requirement that it should be subsidiaries that operate in the legal framework of Ukraine. According to the Law of Ukraine "On Banks and Banking", the bank with foreign capital is a bank in which the share capital that belongs at least to one nonresident exceeds $10 \%$.

As of 01.01.2012 from 176 working banks in Ukraine 53 banks established with foreign capital (compared to as of 01.01.2011 - 55), including 22 - with 100\% foreign capital (on 01.01.2011 - 20 banks). Share of foreign capital in the Ukrainian banking on 01.01.2012 - 41.9\% (on 01.01.2011 - 40.6\%; on 01.01.2010 - 35.8\%; on 01.01.2009 - 36.7\%) (Table 2).

Table 2 - The key indicators of banking activity in Ukraine [8]

\begin{tabular}{|c|c|c|c|c|c|c|c|}
\hline No. & Indicators & 01.01.2007 & 01.01.2008 & 01.01.2009 & 01.01.2010 & 01.01.2011 & 01.01.2012 \\
\hline 1. & $\begin{array}{l}\text { Number of registered } \\
\text { banks }\end{array}$ & 193 & 198 & 198 & 197 & 194 & 198 \\
\hline 2. & $\begin{array}{l}\text { Excluded from the State } \\
\text { Bank Register }\end{array}$ & 6 & 1 & 7 & 6 & 6 & 0 \\
\hline 3. & $\begin{array}{l}\text { Number of banks under } \\
\text { liquidation }\end{array}$ & 19 & 19 & 13 & 14 & 18 & 21 \\
\hline 4. & $\begin{array}{l}\text { Number of banks that } \\
\text { have licenses } \\
\text { performance of banking } \\
\text { operations }\end{array}$ & 170 & 175 & 184 & 182 & 176 & 176 \\
\hline 4.1 & $\begin{array}{l}\text { of which: banks with } \\
\text { participation of foreign } \\
\text { capital }\end{array}$ & 35 & 47 & 53 & 51 & 55 & 53 \\
\hline 4.2 & $\begin{array}{l}\text { including with } 100 \% \\
\text { foreign capital }\end{array}$ & 13 & 17 & 17 & 18 & 20 & 22 \\
\hline 5. & $\begin{array}{l}\text { Share of foreign capital } \\
\text { in the authorized capital } \\
\text { of banks, } \%\end{array}$ & 27.6 & 35.0 & 36.7 & 35.8 & 40.6 & 41.9 \\
\hline 6. & Banks' assets, mln. grn. & 340179 & 599396 & 926086 & 880302 & 942088 & 1054280 \\
\hline 7. & $\begin{array}{l}\text { Bank own capital, mln. } \\
\text { grn. }\end{array}$ & 42566 & 69578 & 11926 & 115175 & 137725 & 155487 \\
\hline 8. & Result of activities & 4144 & 6620 & 7304 & -38450 & -13027 & -7708 \\
\hline
\end{tabular}


In 2008-2009 the share of foreign capital in authorized bank capital fluctuated around the mark of $35 \%$, while in 2011 this figure increased to almost $41 \%$ (Fig. 1). The rapid growth of this indicator began in 2005; to the present the share of foreign capital in authorized capital of banks fluctuated within 10-15\%.

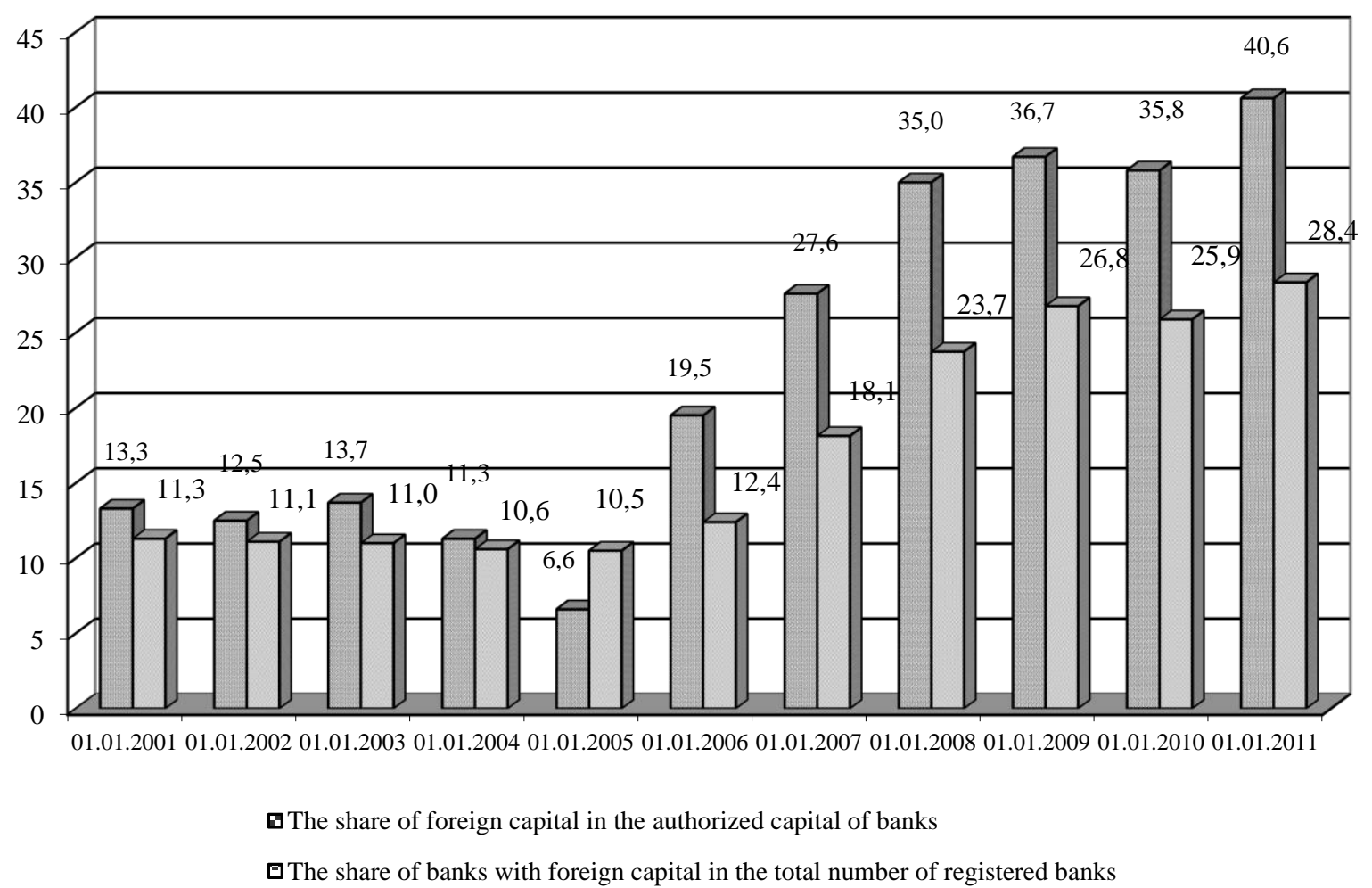

Figure 1 - The relative indicators of foreign capital in the banking system of Ukraine in 2001-2011, \% [8]

The share of foreign capital in the banking systems of EU countries is typically less than 25\% [9], in Norway and the UK subsidiaries of non-residents are created on the basis of reciprocity, the U.S. Federal Reserve may refuse commercial or investment bank being controlled by non-resident in the performance it of functions of the government securities dealer, if national treatment is not extended on the U.S. banks in this area [5].

Today there is no single approach to the limit access of foreign capital in the banking sector of Ukraine. According to the global practice, in any case, the optimal value of this limit should not exceed 49\%. Meanwhile, the Chairman of the Association of Russian Banks G.A. Tosunyan emphasizes the figure of 15-20\% with simultaneous using the principle of reciprocity [9]. 
During 2006-2010 foreign capital in Ukrainian banking sector was received from 17 countries. It should be noted that the most active investors are representatives of the Russian Federation, as for years 2006-2010 Russian financial institutions have purchased five Ukrainian banks, which is about a quarter of all agreements signed during this period. Thus, to the end of 2009 the size of the Russian banking capital in Ukraine has increased to 3.8 billion grn, and t to the end of 2010 investors in the Russian Federation owned 25.1\% of the authorized capital of banks of Ukraine. Other major investors, such as Italy, Austria, France, and Greece have respectively 15.7\%, $14.3 \%, 12.2 \%$, and $6.4 \%$ of the share capital of banks of Ukraine [9].

Evaluation of the activity scope of international financial groups in Ukraine, including financial strength and activity of foreign banks in Ukraine forecasts analysis of those institutions and companies that incorporated.

For this purpose we analyzed the holders of qualifying holding in Ukrainian banks with foreign capital from the point of view of country origin of the capital.

Table 3 - Foreign investors' participation in the authorized capital of Ukrainian banks on 01.01.2012 [8]

\begin{tabular}{|c|c|c|c|c|c|}
\hline № & & $\begin{array}{l}\text { Assets } \\
\text { (mln. \$) }\end{array}$ & $\begin{array}{c}\text { Share capital, } \\
\%\end{array}$ & $\begin{array}{l}\text { Capital } \\
\text { (mln. \$) }\end{array}$ & $\begin{array}{l}\text { Share in the } \\
\text { authorized } \\
\text { capital, \% }\end{array}$ \\
\hline 1 & 2 & 3 & 4 & 5 & 6 \\
\hline 1 & Total for group 1 & 462406 & 10000 & 51261 & 10000 \\
\hline 2 & $\begin{array}{l}\text { including among the countries } \\
\text { of origin equity: } \\
\text { - } \quad \text { Russian Federation } \\
-\quad \text { other countries }\end{array}$ & $\begin{array}{c}97753 \\
364653\end{array}$ & $\begin{array}{l}21,14 \\
78,86\end{array}$ & $\begin{array}{l}14635 \\
36626\end{array}$ & $\begin{array}{l}28,55 \\
71,45\end{array}$ \\
\hline 3 & Total for group 2 & 112539 & 100,00 & 23452 & 100,00 \\
\hline 4 & $\begin{array}{l}\text { including among the countries } \\
\text { of origin equity: } \\
\text { - Russian Federation } \\
\text { - other countries }\end{array}$ & $\begin{array}{c}9128 \\
103411\end{array}$ & $\begin{array}{c}8,11 \\
91,89\end{array}$ & $\begin{array}{c}1248 \\
22204\end{array}$ & $\begin{array}{c}5,32 \\
94,68\end{array}$ \\
\hline 5 & Total for group 3 & 31790 & 100,00 & 5957 & 100,00 \\
\hline 6 & $\begin{array}{l}\text { including among the countries } \\
\text { of origin equity: } \\
\text { - Russian Federation } \\
\text { - other countries }\end{array}$ & $\begin{array}{c}3368 \\
28422\end{array}$ & $\begin{array}{l}10,60 \\
89,40\end{array}$ & $\begin{array}{c}419 \\
5538\end{array}$ & $\begin{array}{c}7,03 \\
92,97\end{array}$ \\
\hline 7 & Total for group 4 & 30528 & 100,00 & 6367 & 100,00 \\
\hline 8 & $\begin{array}{l}\text { including among the countries } \\
\text { of origin equity: } \\
\text { - Russian Federation } \\
\text { - other countries }\end{array}$ & $\begin{array}{c}4589 \\
25939\end{array}$ & $\begin{array}{l}15,03 \\
84,97\end{array}$ & $\begin{array}{c}780 \\
5587\end{array}$ & $\begin{array}{l}12,25 \\
87,75\end{array}$ \\
\hline
\end{tabular}


According to statistics, the banking system of Ukraine can not compete with the banking systems of developed countries for most indicators. According to the National Bank's data registered share capital of Ukrainian banks on January 1, 2012 is 171.865 billion grn. (21.456 billion \$ USA), net assets - 1054.280 billion grn. (131.62 billion \$ USA), i.e., the authorized capital of all banks in Ukraine is approximately equal to the amount of capital of one of the leading foreign banks, and the smallest of the top 10 world banks in the world The Bank of Tokyo-Mitsubishi UFJ Ltd has assets in 11 times more than the entire banking system of Ukraine, demonstrating table 4.

Table 4 - The biggest world banks according to balance value of share capital [10]

\begin{tabular}{|c|c|c|c|c|}
\hline № & Banks & Country & $\begin{array}{c}\text { Assets } \\
(\mathbf{m l n .} \text { \$) }\end{array}$ & $\begin{array}{c}\text { Capital } \\
(\mathbf{m l n} \text {. \$) }\end{array}$ \\
\hline 1. & BNP Paribas SA & France & 2891948 & 19267,10 \\
\hline 2. & $\begin{array}{c}\text { The Royal Bank of Scotland } \\
\text { Groupplc }\end{array}$ & Great Britain & 2739361 & 2623,45 \\
\hline 3. & CreditAgricole SA & France & 2303497 & 38138,50 \\
\hline 4. & Barclays PLC & Great Britain & 2226593 & 4606,81 \\
\hline 5. & DeutscheBank AG & Germany & 2153033 & 2279,77 \\
\hline 6. & UBS AG & Switzerland & 1881246 & 27358 \\
\hline 7. & Lloyds Banking Group plc & Great Britain & 1658736 & 16909,41 \\
\hline 8. & $\begin{array}{c}\text { JP Morgan Chase Bank National } \\
\text { Association }\end{array}$ & USA & 1627684 & 1785,00 \\
\hline 9. & $\begin{array}{c}\text { Societe Generale, Paris La Défense } \\
\text { Lhe Bankof Tokyo-Mitsubishi UFJ } \\
10 .\end{array}$ & France & 1574478 & 1011,56 \\
\hline
\end{tabular}

Transition to the openness of the banking system in Ukraine creates new opportunities for progress, but also has serious dangers. The process of globalization becomes a potential source of risks and conflicts (Figure 2). 


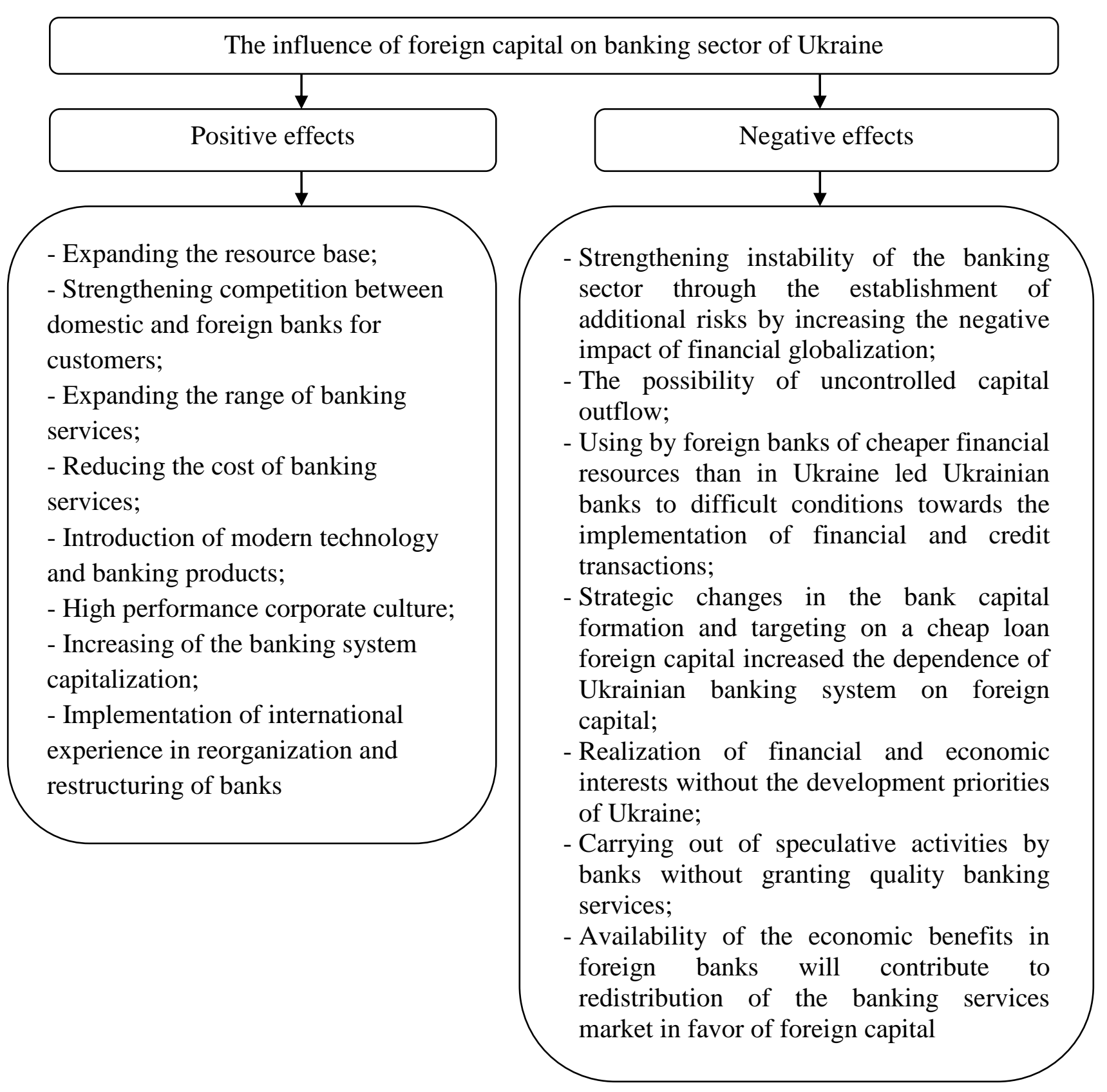

Figure 2 - Influence mechanism of foreign capital in the banking sector of Ukraine

As we can see from the perspective of the foreign capital impact on the banking sector of Ukraine, bank activities with foreign capital together with a number of advantages for both domestic banks and their clients is characterized by risk system. The global financial crisis in 2008-2009 revealed significant deficiencies and serious risks of banks, including foreign capital. Despite the strong support of the parent bank in the country of origin, these banks also suffered noticeable losses. So, Ukrsibbank 
which belongs to a powerful French financial group BNP Paribas suffered losses in the amount of 3,717 million grn. in 2011 [8].

Results. Entry survey of foreign capital into the banking system of Ukraine allowed defining the following general trends and consequences:

1) isolation of the integration processes with limited information on the process of concluding agreements, their characteristics and expected outcomes;

2) quantitative advantage of the acquisition method by purchasing assets, markets and distribution channels within existing market segments;

3) excessive focus on areas of banking which bring immediate, "speculative" income, leveling of innovative banking technologies;

4) most companies have not reached the goals of performance agreements.

Today, among scholars there is no definite opinion concerning effects of increasing the share of foreign capital in the domestic banking system. Thus, according to Baranovsky A. and others presence of foreign capital in the domestic financial market will increase efficiency of Ukrainian banks involving advanced banking technologies; will promote creation of investment resources sources. However, Yepifanov A., Kovalenko V. believe that excessive concentration of foreign capital will cause the complete destruction of the national banking sector. Indeed, the experience of many countries with transition economy, which relied on foreign investment, showed that the banking sector in these countries entirely consist of large international banks, that control the most effective areas of activity, define the nature and priorities of economic development. Studies indicate that banks of developed countries associate the financial market entry with solving domestic economic problems, including increasing profitability of the banking activities by implementing their own competitive advantages, strengthening its position in international markets. Thus, the general approach to impact determination of foreign capital in the banking sector should be based on its restriction on the level in which national control over financial market is remained. In this context the most important issue is determination and establishment of acceptable limits of the foreign capital share for the national banking system. 
Conclusion. To sum up, we believe that to prevent the negative impact of foreign bank capital is necessary to:

- determine the maximum possible level of its concentration on market segments of banking services;

- ensure transparency of foreign investment sources;

- stimulate not only the foreign capital inflow into the banking system, but also the use of modern management and advanced technology of the banking business.

For Ukrainian banks using the foreign banks experience to improve competitiveness in the global financial market, mutual understanding with foreign partners and creating conditions for successful financing through equity markets are important.

In the current context of globalization of the world financial system restructuring of all financial sector takes place. It causes emergence of financial holding companies, insurance companies and banks merges, banks and investment companies' merges. Perimeter of international financial groups in the banking market is changing in the direction of increasing influence of Russian capital on the banking sector of Ukraine.

According to our investigation processes of globalization and integration have important impact on the banking system of Ukraine because of its openness. The manifestation of these processes is the expansion of foreign capital in the domestic market. Bank capital, both domestic and foreign, if it operates in Ukraine should provide effective development of national economy in accordance with policy directions established by government. It is necessary to avoid excessive concentration and monopolization of foreign banking capital in one of the segments of the banking market, to provide appropriate level of transparency of external funds sources, to stimulate not only the flow of investments into the domestic banking system, but also adopt modern management and advanced technology of the banking business. 


\section{References}

1. Van den Berghe L.A.A. Convergence in the Financial services industry [Text] / L.A.A. Van den Berghe, K. Verweire, V.M. Carchon. - OECD. - 1999. - 94 p.

2. Tytell I. Does Financial Globalization Induce Better Macroeconomic Policies? / I. Tytell, Wei. Shang-Jin // IMF Working Paper. - 2004. - WP/04/84 . - P. 15.

3. Барановський О. Іноземний капітал на ринках банківських послуг України, Росії та Білорусі / О. Барановський // Вісник НБУ. - 2007. - № 9. - С. 12.

4. Геєць В. Іноземний капітал у банківській системі України / В. Геєць // Дзеркало тижня. - 2007. - № 26 (605).

5. Коваленко В.В. Стратегічне управління фінансовою стійкістю банківської системи: методологія і практика: монографія / В.В. Коваленко. - Суми: УАБС НБУ, 2010. - 198 с.

6. Спіфанов А. О. Методологічні складові ефективного розвитку банківського сектору економіки України : монографія / А. О. Єпіфанов. - Суми : ВТД «Університетська книга», 2007. - 417 с.

7. Nevmerzytska Olena Features of commercial banks' system restructuring // Challenges for the contemporary enterprise under globalization. Cracow University of Economics, Cracow 2010. - 347 p. [C. 327-332]

8. Офіційний сайт Національного банку України [Електронний ресурс]. Режим доступу : http://www.bank.gov.ua.

9. Кремень В.М. Діяльність фінансових конгломератів на фінансовому ринку України : дис. канд. екон. наук : 08.00 .08 / Кремень Вікторія Михайлівна. Суми, 2009 р. - 243 с.

10. Top Banks in the World by Bankersalmanac.com [Electronic resource]. Available from http://www.bankersalmanac.com/addcon/infobank/bankrankings.aspx.

Korenyeva, O. G. The influence of globalization and integration process on the activities of the banking system of Ukraine [Text] / O. G. Korenyeva, L. Yu. Sysoyeva, I. V. Belova. - Przemysl : Nauka i Studia. - 2012. - NR 4(49). - P. 103112. 